\title{
Disease management of major grain legumes and breeding strategies in Nepal
}

\section{Introduction}

Grain legumes play an important role in Nepalese agriculture contributing towards food and nutritional security, nitrogen economy, crop intensification, diversification and sustainable farming systems. Grain legumes rank fourth in terms of acreage (about $10.8 \%$ of total cultivated land) and $5^{\text {th }}$ in production. Grain Legumes Research program (GLRP) of Nepal in collaboration with CGIAR centers works for genetic improvement of lentil, chickpea, pigeonpea, soybean, mungbean, blackgram, grasspea, fababean and cowpea. Lentil is the main grain legumes crop in Nepal $(62 \%$ area and $64 \%$ production of the total legume. ${ }^{1}$ It is recognized as one of the major agricultural produce among 12 goods with high export potential and medium socio-economic impacts by Nepal Trade Integration Strategy (NTIS). Lentil alone contributes about 2.3 percent of total national exports and shares about 3.1 percent of the total lentil export in the world. ${ }^{2}$

Grain legumes crops are vulnerable to range of diseases, mostly caused by fungi, parasitic angiosperms, viruses, and bacteria. In some instances, $100 \%$ yields losses have been reported. The yield potential of these crops is seldom achieved due to the cultivation of susceptible cultivars and lack of proper crop management practices to cope with these biotic stress factors. During the last three decades food legumes scientist have been working to develop ways to tackle these biotic stresses through host plant resistance and by adopting various management options. In many case such measures have been recommended in combination or singly. However, host plant resistance is the most economical, long term, environmentally acceptable means of controlling these biotic agents. In most of the grain legumes, germplasm has been collected, conserved at national and international levels characterized and used in genetic enhancement programs to develop improved varieties that are resistant to single and multiple stress factors. In the past, breeders have focused on yield and quality only, later on progress has been made to incorporate disease and pest resistance as key components of genetic enhancement programs. Genetic control of the major biotic stresses has been resolved and the information has been used in breeding programs. Very recently, biotechnological approach has been adopted to tag molecular markers with resistance genes to enhance breeding efficiency through marker assisted selection. The transgenic technology also offers opportunity to genetic enhancement where genes for resistance are not available in nature. In this paper; attempted to enhancement in combating biotic stresses in a range of major grain legumes; lentil, chickpea, soybean, cowpea, mungbean, blackgram, pigeonpea and Rajma bean.

\section{Some principles underlying selection for disease resistance}

i. Genetic resources for resistance must be identified from existing materials: cultivar itself, commercial cultivars, other varieties, land races, weedy relatives, related species or genera.

ii. Screening technique for resistance by exposure to the disease pathogen under natural or artificial induced epiphytotic is necessary to distinguish between resistance and susceptible plants.
Volume 6 Issue I - 2017

\author{
Rajendra Darai,' Ojha BR, ${ }^{2}$ Krishna Hari \\ Dhakal $^{2}$ \\ 'Nepal Agricultural Research Council (NARC), India \\ ${ }^{2}$ Department of Genetics and Plant Breeding, Agriculture and \\ Forestry University (AFU), India
}

Correspondence: Rajendra Darai, Nepal Agricultural Research Council (NARC), Grain Legumes Research Program, Khajura, Nepalgunj, Nepal, India, Email rajendra5042@yahoo.co.uk

Received: May 10, 2016 | Published: January 16, 2017

iii. Mode and inheritance of resistance must be understood.

iv. The resistance gene must be transferred to an adapted cultivar.

v. Progeny testing of resistant plants to verify the inherent nature of resistance.

\section{Breeding approaches for disease resistance}

The various approaches for breeding disease-resistant varieties are discussed below

Avoidance (Disease escaping varieties): It reduces the chance of contact between prospective host tissue or food plant and a potential natural enemy usually as a result of particular morphology, phenology or smell of the potential host plant. Mimicry, camouflage, thorns, hairs, spines, smell, color, taste, repellent odors are some of the examples.

Resistance: It is the ability of the host to reduce the growth and or development of the parasite or pathogen. It is of 2 types:

i. Race specific/vertical resistance/gene for gene resistance: A resistance that is effective to specific (a virulent) genotypes of a pathogen species.

ii. Race nonspecific/horizontal resistance/no gene for gene resistance: A resistance that is equally effective to all the genotypes of a pathogen species.

Tolerance: It neither restricts parasitic contact nor the growth and development of the parasite after establishment. As a consequence, it does not affect the amount of damage/symptoms per unit quantity of parasite present.

Susceptibility: Incapacity of a plant to reduce the growth, development and reproduction of the natural enemy.

Sensitivity: Character of the host plant to develop relatively severe symptoms or severe damage per unit quantity of the natural enemy.

Replanting of discarded varieties.

Cultivar diversification. 


\section{Gene for gene relationship}

i. Flor 1956 based on his work on linseed rust postulated the gene for gene relationship between a host and pathogen. This relationship states that "A resistance gene, $\mathrm{R}$ is only effective if the infecting pathogen carries the corresponding avirulence gene, A"

ii. Host resistance is conditioned by dominant allele, $R$.

iii. In the pathogen, virulence is conditioned by recessive allele, a.

iv. Resistance reaction occurs when complementary genes in both host and pathogen are dominant.

v. A host genotype that carries no dominant alleles at any of the loci is susceptible for all the races of pathogen (even if avirunlent).

vi. 'A' avirunlent allele is dominant over ' $a$ ' virulent allele and resistant allele ' $R$ ' is dominant over susceptible allele ' $r$ '.

vii. Compatibility depends on the genotype of the host and the genotype of the pathogen.

\section{Major diseases of grain legumes in Nepal}

Working with various species of grain legumes for the last few decades, grain legumes scientists have been identified several biotic agents, which substantially limit crop productivity and cause instability. Some of these agents pose a serious threat to the existence of the crops as well. Due to yield instability and high risk cultivation caused by various biotic stresses, farmers in many countries have abandoned the cultivation of some grain legumes, thus posing a severe threat to the sustainability of whole crop production system. Considering all these facts, several authors have reported the effects of numerous major and minor biotic factors, symptoms of the disease and its breeding strategies has been drawn as Table 1 .

Table I Diseases of chickpea

\begin{tabular}{lll}
\hline S. No. & Disease causal organism & $\begin{array}{l}\text { Economic } \\
\text { importance }\end{array}$ \\
\hline $\mathbf{1}$ & Botrytis gray mold Botrytis cinerea & Major \\
$\mathbf{2}$ & Wilt Fusarium oxysporum f sp. ciceri & Major \\
$\mathbf{3}$ & Black root rot Fusarium solani & $\begin{array}{l}\text { Major in some } \\
\text { locality }\end{array}$ \\
$\mathbf{4}$ & Collar rot Sclerotium rolfsii & $\begin{array}{l}\text { Major in some } \\
\text { locality }\end{array}$ \\
$\mathbf{5}$ & Dry root rot Rhizoctonia bataticola & Sometime major \\
$\mathbf{6}$ & Stem rot Sclerotinia sclerotiorum & Minor \\
$\mathbf{7}$ & Alternaria blight Alternaria alternata & Minor \\
$\mathbf{8}$ & Stunt Bean leaf roll virus & Minor \\
$\mathbf{9}$ & Proliferation Cucumber mosaic virus & Minor \\
$\mathbf{1 0}$ & Phyllody Mycoplasma (Cesame phyllody) & Minor \\
\hline
\end{tabular}

Diseases of Lentil (Table 2)

Annex ii.A list of lentil diseases reported in Nepal.

\section{Blackgram/Mungbean diseases}

Mungbean Yellow Mosaic Virus (MYMV): MYMV Gemini virus; transmitted by white fly (Bemisia tabaci) and important host crops are blackgram, mungbean, soybean, cowpea and pigeonpea. The disease prone areas are hot and humid areas of terai/inner terai and foot hills.

Cercospora leaf spot (Cercospora canescens): This disease, basically seed borne, is an important both in hills and terai/ inner terai. Several sources of resistance to powdery mildew have been reported from India and Phillipines.

Anthracnose (Colletotrichum lindemuthianum): Reddish-brown, elongated and sunken lesions can be observed on cotyledons of the germinating seed, leaf, peduncle, branches and main stem and lesions are also found on pods and seed. Lesions coalesce each other and form large patches.

Powdery mildew (Erysiphe polygoni): This disease is more important in mid hills. White powdery patches appear on leaves and other green parts. Later the patches become dull coloured and are studded with black, dot-like cleistothecia.

Web blight (Rhizoctonia solani): Initial symptoms are small circular brown spot which enlarge and often show concentric banding and become surrounded with irregular shaped water soaked areas. Under humid conditions the lesions develop rapidly and coalesce leading to extensive blighting and defoliation. Large creamy white sclerotia are formed on infected parts.

Bacterial Leaf Blight (Xanthomonas phaseoli): It is characterized by many brown, dry and raised spots on the leaf surface. When the disease is severe several such spots coalesce, the leaves become yellow and fall off prematurely. The lower surface of the leaf appears red in colour due to the formation of raised spots. The stem and pods also get infected. The bacterium is seed-borne and through vines grow.

Alternaria leaf spot (Alternaria alternaria A. tenuissima): The disease occurs rarely on green gram and can be seen in all the seasons. Initially, small, circular brown spots appear on the leaf surface. Gradually, the spots become dark brown with concentric circles. As the severity increases, the spots enlarge and the concentric rings become clearly visible. Affected portions in the leaf get separated and fall down resulting in shot holes.

\section{Soybean diseases}

Mungbean Yellow Mosaic Virus (MYMV): MYMV is the most important disease problem of soybean in terai and inner terai. The disease damages the crop in terms of both quality and quantity. The causal virus has a wide range of alternate and collateral hosts and easily transmitted by white fly. A single white fly is sufficient to transmit the virus from infected plant to healthy plants. Abundance of weed hosts specially Ageratum spp has been one of the major causes of high disease severity in Chitwan. Symptoms and management are same as in the case of blackgram. Ridge planting in soybean might reduce whitefly population by allowing air drainage between rows.

Soybean mosaic virus: Symptoms include mosaic, mottling of leaves accompanied by a slight crinkling and reduction in size. Plants become stunted and set a few pods only. Pods and seeds are reduced in size. It is an aphid and seed transmitted virus that infects soybean plants and causes significant yield losses. Management includes the use of virus free seed and control of aphid vector.

Bacterial pustule (Xanthomonas campestris pv. glycines): This is an important disease of terai / inner terai and mid hills. This disease reduces both quality and quantity of soybean. The disease starts with 
numerous pin headed dark brown spots on leaves. The spots become slightly raised and occur on one or both surfaces of leaves. The spots turn reddish brown. The spots later become irregular in shape and larger with grey center. Small reddish- brown spots also occur on pods. Diseased crop gives a yellowish outlook. Rainy and windy weather favors spread of the disease.

Leaf spot (Cercospora sojina): Numerous typical zonate grey spots with purplish brown margin appear on leaves and other parts of the plant except on the roots. Spots develop as brown or red areas with grey centers and purplish borders. Spots may be round or angular in shape. Spots coalesce each other and form large lesions. In severe cases the plants become completely defoliated. Purple stain is often observed on seed coat.

Pod blight and anthracnose (Colletotrichum truncatum): Pods turn yellowish and later turn brown. Seed formation is adversely affected. Numerous acervuli of the fungus are formed on the pods. On the leaves, petioles and stem dark brown sunken lesions are formed. The mycelium of the fungus over winters is in seed or diseased plant debris. Sclerotium of the fungus hibernates in soil in crop stubbles.

\section{Cowpea diseases}

MYMV : The same as in the case of blackgram/mungbean.

Anthracnose: Reddish brown, elongated and sunken lesions can be observed on cotyledons of the germinating seed, leaf, peduncle and main stem. Lesions are also found on pods and seed. Lesions coalesce each other and form large patches.

Powdery mildew: Same as in the case of blackgram and mungbean.

Cercospora leaf spot: Leaf spots are circular measuring $1 \mathrm{~cm}$ in diameter. As the disease advances dark brown lesions go on increasing on the upper surface of the leaves and fungal outgrowth is observed on the opposite side of the lesions. The fungus survives in seed, diseased crop stubbles and other alternate hosts.

\section{Pigeonpea diseases}

Pigeonpea Sterility Mosaic Disease (SMD): The virus causes mosaic symptoms on leaves and infected plants do not flower thus named sterility mosaic. Appearance of dwarf, pale green, sterile plants in isolated pockets is the most conspicuous symptom of the disease. If infection occurs after 45 days of planting few branches exhibit disease symptoms while rest of the branches remain normal.

Wilt of pigeonpea (Fusarium udum Butler): Appearance of wilted plants in patches at the time of flowering or pod set is the first indication of the disease. Advancement of the purple lesion from lower stem upward is an important symptom of the disease. Purple lesion is conspicuous on green stem. Partial wilting is observed in case of damage to secondary roots while whole plant shows wilting if primary roots are damaged. Young plants may not show purple patch. Nevertheless, underlying tissues (xylem) become brown or black. Foliar symptoms include fading away of interveinal portion with leaves turning light yellow to bright yellow.

Leaf spot (Cercospora indica): Small, light- brown, interveinal leaf spots with dark- brown centers, coalescing to form bigger spots. Later the leaves dry curl and fall off. Sometimes grayish black elongated lesions are formed on petioles and stem. Profuse dark olivaceous mycelial growth can be seen on the under surface of the leaves during wet weather.
Botrytis gray mold (Botrytis cineria Pers ex Fr.): The disease generally appears at the time of flowering. Dark grey fungal growth is observed on twigs, and pods. Flowers drop and set few pods. Grey mass of fungal spores are observed on fallen flowers and leaves.

\section{Breeding strategies for summer grain legumes}

Host resistance breeding: Several mungbean varieties with high level resistance to MYMV were found in Grain Legumes Research Program, Khajura Nepal; like Pratikcha, Kalyan, BARI Mung-1, VC6173(B-10), HUM-16, IPM-16,VC 6368 (46-7-2), VC 6173(B-33), VC 6144 (49-28-2), VC 6875(41-113-6), VC 6173C, VC 6153 (B19), VC 3960-88).

i. Similarly in blackgram genotypes IPU-2002-1, Pant-U 31, IPU2002-2, BLG0067-1, BLG003-2-1 were highly resistant to mungbean yellow mosaic virus (MYMV) while BLG0055-1-1, Bari Mash 1, Bari Mash 2 and Bari Mash 3 were resistant and BLG0001-2, 0035-1, -0016-1, -0012-3 were moderately resistant to MYMV.

ii. Resistance to MYMV and bruchids were introgressed through wide crosses, V. radiata x V. radiate var. sublobata. Useful disease resistance genes were also identified from amphidiploids of mungbean $\mathrm{x}$ ricebean crosses.

iii. Mutation breeding has led to the development of several large seeded, high yielding and MYMV resistant lines. Of these, NM51 and NM-54 were released in Pakistan. Mutagenic treatments have been used for generating variability for resistance against a number of diseases i.e. CLS, MYMV and powdery mildew.

iv. Combinedresistancetoanthracnose, cercosporaleafspotandMYMV (Blackgram varieties LU1129, PLU117,PLU1077,UG218,UG786 and UG1100) and a line TEU95-1 that posses multiple resistance to anthracnose, cercospora leaf spot, powdery mildew and MYMV have been reported.

v. For the web blight, the disease could be managed by growing less susceptible varieties (erect type), practicing crop rotation, discouraging high vegetative growth and shady situation and field sanitation.

vi. In case of soybean MYMV; genotypes Puja, PK327, LS77-16-16, AGS376, CM 9125, SB0065, SB0095 were resistant to Mungbean Yellow Mosaic Virus (MYMV) and IARS-87-1, Chaing Maw 6063, CM 9133, Dhankuta, SJ 4 were moderately resistant.

vii. In case of cowpea grow early genotypes IT99K-464-6, IT98K-205-8, IT99K-530-1, IT00K-1217, medium duration IT03K-337-6, IT98K-503-1 and dual purpose IT04K-227-4, IT06K-147-2, IT99K-573-1-2, IT99K-573-1-1 were found the YMV disease free at Rampur.

viii. In case of sterility mosaic, some of the host plant resistant varieties with high yield potential cultivated in India are KPL-44, Amar, Narendra Arahar-1,Pant A 8505, Pant A 8508, BSMR853, ICPL8860, BWR27, ICPL366 while in Nepal ICPL7035, Bageswori, Rampur Rahar-1 and ICPL86005 are the sterility resistant varieties.

ix. Systematic and intensive work on identification of sources of resistance and development of wilt resistant varieties in Nepal by NARC/GLRP has paid rich dividends for the wilt (Fusarium sp); it is suggested a three year crop rotation with non-host crop and use 
of disease resistant varieties/ cultivars like ICP 7035 (mid-western terai), ICPL88039, ICPL86005 etc.

\section{Major disease of winter grain legumes \\ Chickpea diseases}

Botrytis gray mold: Causal organism is Botrytis cinerea. Lack of pod setting is the first indication. Under favorable conditions, foliage shows symptoms and plants often die in patches. Shedding of flowers and leaves, covered with spore mass can be seen. Lesions on stem are 10-30 $\mathrm{mm}$ long and girdle the stem fully. Tender branches break off at the point where the gray mold has caused rotting. Affected flowers turn in to a rotting mass. Lesions on the pod are water-soaked and irregular. On infected plants, the pods contain either small, shriveled seeds or no seeds at all. Basically a disease is a seed-borne disease. It survives on infected chickpea debris and remains infective up to 8 months. Excessive vegetative growth due to irrigation or rain, close spacing and varieties that have spreading habit favor the disease development.

\section{Breeding strategies and progress}

i. Cinerea isolates collected from India and Nepal have been differentiated based on their morphocultural characters and effects on different chickpea genotypes. ${ }^{3,4}$

ii. Nine simple sequence repeat markers were used on B. cinerea ${ }^{5}$ to study population structure of a total of 51 alleles were amplified among $146 \mathrm{~B}$. cinerea isolates of chickpea from Bangladesh, India and Nepal, which revealed a high amount of within-population and overall genetic diversity. ${ }^{6,7}$

iii. Different methods have been applied to screen germplasm for BGM resistance under in vitro, greenhouse and field conditions. ${ }^{8-10}$

iv. The cut-twig technique allows for non-destructive sampling of the plants and is particularly useful in wide hybridization programs. ${ }^{8,9}$

v. High levels of resistance have not been found in cultivated chickpeas. ${ }^{11,12}$

\section{Cultural control method}

i. Avoid excessive vegetative growth

ii. Intercrop with linseed

iii. Avoid excessive irrigation

iv. Use resistant varieties

v. Deep summer ploughing

vi. Reduce plant density and increase in air passage between the plants.

\section{Mechanical control}

Use Trichoderma spp as bio-control agents.

\section{Fusarium wilt}

Causal organism of the disease is Fusarium oxysporum f.sp.ciceri. The disease can affect the crop at any stage. The field symptoms of wilt are dead seedlings or adult plants, usually in patches. At seedling stage, 3-5weeks after sowing, whole seedlings collapse and lie flat on the ground with dull green leaves and shrunken stem. Dark drown or dark discoloration of the internal stem tissues is visible. At adult stage, drooping of petioles, rachis and leaflets and finally entire plant occurs. The fungus is seed and soil borne. Warmer and drier climates $\left(>25^{\circ} \mathrm{C}\right)$ favor disease and also when crop rotations are not practiced.

\section{Cultural control}

i. Resistance to Fusarium wilt is race specific and hence controlled by major resistance genes

ii. Deep summer ploughing

iii. Grow cultivars resistant to wilt

iv. Practice soil solarization

v. In fields with a history of Fusarium do not grow gram for 3years.

vi. Follow crop rotation measures continuously.

vii. Always use disease free seeds.

viii. Avoid sowing when temperatures are high.

ix. Follow 6-year crop rotations with sorghum

x. Apply FYM 10-15 cart load/ha.

\section{Biological control}

i. Apply Trichoderma viride @ 4g/kg seed reduces disease incidence.

ii. In Nepal, host resistant lines ICCV03107, ICCV03213, ICCV04105,ICCV04106, ICCV05109, ICCV05110, ICCV92337, ICCV93207, ICCV95432, ICCV03111, KPG59 were found resistant to wilt root rot disease.

\section{Collar rot}

Causal organism of the disease is Sclerotium rolfsii. It comes in the early stages i.e up to six weeks from sowing. Drying plants whose foliage turns slightly yellow before death, scattered in the field is an indication of the disease. Seedling becomes chlorotic. The joint of stem \& root turns soft slightly contracts and begins to decay. Infected parts turn brown white. Black dots, like mustard in shape known as sclerotia are seen appearing on the white infected plant parts. It can be survived in high soil moisture; low soil $\mathrm{pH}$ and high temperature are favorable. The presence of undecomposed organic matter on the soil surface and high moisture at the time of sowing and at the seedling stage favor disease development. Disease incidence is higher when sown after rice or early sown crop. ${ }^{13-16}$

\section{Cultural control}

i. Deep ploughing in summer

ii. Avoid high moisture at the sowing time

iii. Seedlings should be protected from excessive moisture

\section{Mechanical control}

i. Destroy the residues of last crop and weed before sowing and after harvest.

ii. All un-decomposed matter should be removed from the field before land preparation. 


\section{Dry root rot}

Causal organism of the disease is Rhizoctonia bataticola Macrophomina phaseolina. The disease appears from flowering to pod setting stage as scattered dried plants. The leaves and stem becomes straw colored. Affected plants wither and spread across the entire field. The roots of infected plants become brittle and dry. The survival \& favorable conditions is found in maximum temperatures above 30 degree and dry soil conditions and moisture stress promote disease development

\section{Cultural control}

i. Deep ploughing in summer

ii. Grow cultivars resistant to dry root rot.

iii. Drought should be avoided.

iv. Sowing should always be done on the recommended time.

v. Germinating and young seedlings should be saved from high temperatures.

vi. Seed treatment with Trichoderma viridae formulation can reduce the disease incidence.

\section{Diseases of lentil (Table 2)}

Annex ii. A list of lentil diseases reported in Nepal.

Fusarium wilt: Causal organism of the disease is Fusarium oxysporum f.sp. lentis and occurs in all lentil growing areas of Nepal. It survives in soil and also associated with seed (seed-borne). The disease appears in the field in patches at both seedling and adult stages. The adult wilt symptoms appear at flowering to late pod-filling stage characterized by sudden drooping of top leaflets. Leaflet closure without premature shedding. Dull green foliage color followed by wilting of the whole plant or individual branches. Apparently healthy looking root system is with a slight reduction in the lateral roots to pull as the healthy plant, and no internal discoloration of the vascular system.

\section{Management}

i. The best method is use resistant and moderately resistant varieties as Shikhar, Simal, Shital, Khajura 2, Sagun, and Maheswor Bharati

ii. Cultural: Crop rotation with cereals

iii. Biological: Soil treatment with Trichoderma harzianum @ $10 \mathrm{~kg} / \mathrm{ha}$ found effective for the control of wilt/root of lentil.

iv. Trichoderma koningii seed treatment $(5 \mathrm{~g} / \mathrm{kg})$ also effective for wilt and root rot Genotypes ILL 7164, ILL 7716, ILL 7986, ILL 2526 were found resistant to wilt/ root rot complex.

v. Khajura Masuro-1, Simal, Shital, ILL 1704, Baitadi 6A, PL 406, LN0136, ILL 6821, Shikhar, ILL 8188, Mangal bazaar, ILL 3490, and Arun were moderately resistant.

vi. Wilt susceptible check Sindur was found moderately resistant to wilt/root rot complex.

vii. In Nepalgunj, genotypes ILL 6025, F2003-49L, LN0137, ILL7716, LN0136, ILL 6465, ILL 8188 and Arun showed no mortality due to Fusarium wilt.
Stemphylium Blight: Stemphylium blight is major disease of lentil in Bangladesh and Nepal. Serious threat to lentil cultivation especially is in terai, inner terai and foot-hills of Nepal. The pathogen was found in samples collected from Banke, Bardia, Rupandehi, Chitwan, Makwanpur, Bara, Parsa, Rautahat. It indicates wide spread nature of the disease. Leaflet tips are discolored in a way similar to that incited by certain mineral deficiencies. Infected leaves and branches becomes blighted dull yellow. Within few days infected leaflets shed, yield losses due to stemphylium blight up to $93.4 \%$ in susceptible cultivars.

Table $2 \mathrm{~A}$ list of lentil diseases reported in Nepal

\begin{tabular}{|c|c|c|}
\hline Disease & Causal Organism & Reference \\
\hline Fungal: Wilt & $\begin{array}{l}\text { Fusarium oxysporum f.sp. } \\
\text { lentis }\end{array}$ & Manandhar \\
\hline Collar rot & Sclerotium rolfsii & Karki \\
\hline Black root rot & Fusarium solani & Manandhar \\
\hline Dry root rot & Macrophomina Phaseoli & Manandhar \\
\hline Wet root rot & Rhizoctonia solani & NGLRP \\
\hline Stem rot & Sclerotinia sclerotiorum & Bayaa \\
\hline Stemphyllium blight & Stemphylliumbotryosum & Joshi \\
\hline Rust & Uromyces fabae & \\
\hline Grey mold & Botrytis cinerea & \\
\hline Powdery mildew & Oidium sp & \\
\hline Alternaria blight & Alternaria alternata & \\
\hline Yellowing & Cladosporium herbarum & \\
\hline Cercospora & Cercospora lensi & \\
\hline Anthracnose & Colletotrichum sp. & \\
\hline \multirow[t]{5}{*}{ Nematodes } & $\begin{array}{l}\text { Helicotylenchus sp., } \\
\text { Tylenchus sp., }\end{array}$ & $\begin{array}{l}\text { Manandhar } \\
\text { and Amatya }\end{array}$ \\
\hline & $\begin{array}{l}\text { Criconemoides sp., } \\
\text { Aphelenchus sp. }\end{array}$ & PPD \\
\hline & \multicolumn{2}{|c|}{ Tylenchorynchus sp., Pratylenchus sp. sp., } \\
\hline & \multicolumn{2}{|l|}{ Haplolaimus sp. Trichodorus sp. } \\
\hline & \multicolumn{2}{|c|}{ Rotylenchulus sp. Meloidogyne sp. } \\
\hline \multirow[t]{4}{*}{ Viral } & Cucumber mosaic virus & NGLRP \\
\hline & Pea seed-borne mosaic virus & Joshi \\
\hline & \multicolumn{2}{|l|}{ Cucumber mosaic virus } \\
\hline & \multicolumn{2}{|l|}{ Pea seed-borne mosaic potyvirus } \\
\hline
\end{tabular}

\section{Management}

i. Use of moderately resistant variety as Shikhar, Simal, Maheswor Bharati, Bari masuro 4, Bari masuro3.

ii. Cultural control: wider spacings $30 \mathrm{~cm}$.

iii. Resistant/moderately resistant variety + with wider spacing $(30 \mathrm{~cm})$ + Dithane M-45 spray after flowering.

iv. Genotypes ILL 7715, ILL 8191, Arun, Simrik, ILL 4402, ILL 6467, ILL 8603, ILL 2780, and 39S-66L showed field tolerance to Stemphylium blight. 
v. ILL 9950, ILL 7537, ILL 9992, ILL 4402, ILL 2700-1, ILL 9881, ILL 6024, ILL 6025, CUMARA, AURUN, SHISHIR, ILL 9924, ILL 2712, X 94-S-38, RL-9 and RL-27 are moderately resistant to disease.

\section{Research facts}

i. Occurrence of disease is most common and destructive in all lentil growing areas of Nepal.

ii. Severe in Bara, Parsa, Chitwan, Banke Rupandehi and very common-damaging in Rautahat, Dang, Bardiya, Nawalparsi and Makwanpur.

iii. Gradual increase in atmospheric temp. and change in rainfall, relative humidity and sunshine hour seem to have contributed in wide spread outbreak Xanthoxylum armatum, Acorus, calamus and Lantana camera inhibited radial mycelial growth at different concentrations.

iv. Except Artimisia indica and Azdirachta indica at a lowest dose also inhibit the mycelial growth.

Rust: The causal pathogen is Uromyces fabae. Rust is not widespread in Nepal, while during some seasons appears late in the crop. The symptoms start with the formation of yellowish-white pycnidia, aecial cups on leaflets and pods, singly or in small groups in a circular form. Later, brown uredial pustules, oval to circular and up to $1 \mathrm{~mm}$ in diameter and develop on either surface of the leaflets, branches, stem and pods. They may coalesce to form larger pustules. The telia, which are formed late in the season are dark brown to black, elongated and are present mainly on branches and stem. In severe infections, the affected plant dries without forming any seeds in pods or with small shriveled seeds. The plant has a dark brown to blackish appearance, visible in affected patches of the field or in the whole field if it is totally infected.

\section{Management}

Use of resistant or moderately resistant varieties as ILL 7164, ILL 7723 and Shital recommended.

\section{Diseases of rajma}

White Mold: The pathogen is Sclerotinia sclerotiorum. The damage symptoms are serious losses in recent years. Economically this disease is more important in snap beans than dry beans. A low incidence lowers the grade or increases the cost of processing. This difference may be due to variation in weather patterns, natural vegetation, and soil characteristics that result in extended periods of wet soil and moisture on the plants. Widely distributed in most cool, wet areas of the world. In part, this is because it can infect more than 360 species of plants. Symptoms of the disease are usually first visible about one week after full bloom because blossoms generally are the first part of the plant to be colonized by the fungus. Leaves, stems, and pods in contact with the colonized blossoms can then become infected, provided moisture is present. Initial symptoms on these tissues are pale colored, water-soaked lesions. These lesions enlarge and within a few days become covered with a white, cottony fungal growth. Leaves of severely diseased plants become yellow and eventually turn brown and fall off. As the disease progresses, the infected plants wilt and the leaf canopy opens. The fungus may eventually invade and kill all above ground parts of the plants.

\section{Management}

i. Use resistant varieties: PDR -14.

ii. Seed treatment: Thiophenate methyl $(3 \mathrm{gm} / \mathrm{kg})$.

iii. Not much use of Nitrogen fertilizer.

iv. Last week of Ashoj and first/second week of Mangsir (cultivation).

v. Plant density optimum.

vi. Avoid cultivation in shed area.

vii. Severity was high even with Aswin 25 and Mangsir 5 plantings in Hetaude and Utkarsha.

viii. PDR -14 had low disease severities with early and late plantings with sustainable yield.

ix. PDR-14 and Amber had least disease severity with sustainable yield.

\section{Acknowledgements}

None.

\section{Conflict of interest}

The author declares no conflict of interest.

\section{References}

1. MOAD. Statistical information of Nepalese Agriculture, Government of Nepal, Ministry of Agriculture Development; 2013.

2. USAID. Value chain/market analysis of the lentil sub-sector in Nepal. Nepal Economic Agriculture, and Trade Activity, Kathmandu, Nepal: USAID; 2011

3. Rewal N, Grewal JS. Effect of temperature, light and relative humidity on conidial germination of three strains of Botrytis cinerea infecting chickpea. Int Phytopathology. 1989;42:79-83.

4. Kishore GK. Cultural, morphological, pathogenic and genetic variation in Botrytis cinerea, causal agent of gray mold in chickpea. $\mathrm{PhD}$ Thesis, Jawaharlal Nehru Technological; 2005.

5. Fournier E, Giraud T, Loiseau A, et al. Characterization of nine polymorphic microsatellite loci in the fungus Botrytis cinerea (Ascomycota). Mol Ecol Notes. 2002;2:253-255.

6. Isenegger DA, MacLeod WJ, Ford R, et al. Genetic structure of Botrytis cinerea that causes Botrytis grey mould disease of chickpea in Bangladesh. In: Innovations for sustainable plant health-15th Australian Plant Pathological Society handbook; 2005. 224 p.

7. Isenegger DA, Macleod WJ, Ford R, et al. Genotypic diversity and migration of clonal lineages of Botrytis cinerea from chickpea fields of Bangladesh inferred by microsatellite markers. Plant Pathol. 2008;57(5):967-973.

8. Pande S, Singh G, Rao JN, et al. Integrated management of Botrytis gray mold of chickpea. Information Bulletin No. 61, Andhra Pradesh, India: ICRISAT; 2002.

9. Pande S, Krishna Kishore G, Upadhyaya HD, et al. Identification of sources of multiple disease resistance in mini-core collection of chickpea. Plant Dis. 2006;90(9):1214-1218.

10. Pande S, Siddique KHM, Kishore GK, et al. Ascochyta blight of chickpea (Cicer arietinum L.): a review of biology, pathogenicity, and disease management. Aust J Agric Res. 2005;56:317-332. 
11. Gurha SN, Singh G, Sharma YR. Diseases of chickpea and their management. In: Ali M, et al. editors. 2003

12. Haware MP, McDonald D. Botrytis gray mold of chickpea. In: Haware $\mathrm{MP}$, et al. editors. Recent advances in research on Botrytis gray mold of chickpea. Patancheru: ICRISAT; 1993. p. 3-6.

13. Haware MP, Nene YL. Screening chickpea for resistance to Botrytis gray mold. Int Chick News. 1982;6:17-18.
14. Annual report 2011-2013 GLRP. Khajura.

15. ITC; 2011.

16. Ojha BR. A note for resistance breeding; 2015. 